\title{
Designing and Implementing an Effective Courseware for the Enhancement of e-Learning
}

\author{
http://dx.doi.org/10.3991/ijet.v11i04.5384 \\ Wesam Karajeh, Thair Hamtini and Meysun Hamdi \\ The University of Jordan, Amman, Jordan
}

\begin{abstract}
The objective of this study is to determine the effect of applying the cognitive theory of multimedia learning in an e-learning environment. Three versions of a course on how to master skills in Adobe Photoshop were designed and given to a sample of (60) students to test their effectiveness. This research sample was divided into three groups. The first was an experimental group that studied the subject through Course Facilitated Multimedia Principles (CFMP), like the multimedia principle, the modality principle and the contiguity principle. The second experimental group studied the subject through Course Not-Facilitated Multimedia Principles (CNFMP), which did not apply the multimedia principle. The last group is a control group that studied the subject through traditional methods. Learning outcomes were determined by achievement test. Differences between pre and post-test scores were analyzed. The results show that the students in the first experimental group had improved their academic achievement by $53.70 \%$, while the students in the second experimental group improved by $45.80 \%$. Finally, the students in the control group had improved their achievement only by $30.5 \%$. The findings affirm that CFMP has more effect on student achievement than the traditional way or the CNFMP. This is an indication that the application of the multimedia principles has improved the students' ability to comprehend, and achieved higher levels in learning. We recommend that educators should continuously examine the effectiveness of their pedagogical strategies and smartly apply technologies to enhance student's learning.
\end{abstract}

Index Terms-e-Learning, Courseware, Multimedia principles, Students' achievement.

\section{INTRODUCTION}

Electronic learning (e-Learning) plays an increasingly important role in education to enhance learning and teaching activities; it refers to any instruction that is delivered via a computer and that includes content relevant to the learning feature, uses a variety of media elements to deliver the content, and employs methods to build new knowledge and skills linked to improved organizational goals. Such courses may be synchronous, asynchronous, instructor-led or computer-based, or a combination of all those methods. E-Courses provide a valuable e-Learning environment. If students are able to master the skills to use this environment and develop a positive attitude towards it, then such an environment can form a basic foundation for significant positive developments in the curriculum, teaching methods and student evaluation.

Educational computer technology is a new way to enhance the basic structure of the educational field for all scholastic stages. This includes the development of in- structors and administrators skills, development of the curriculum and delivery of courses, and use of the direct educational programs and systems. Such an eco-system requires the usage of the internet and the intranet at schools and universities as one of the basic needed means in implementing, using and applying these new education tools and technology systems. Computer-aided learning shows the self-learning component, which means it gives feedback on how students learn by themselves and how well they retain this learning for the rest of their practical lives.

\section{A. E-Learning Properties}

E-Learning is different from other traditional teaching models in its nature and in its philosophy. Traditional education depends on textbooks and does not use any technological means or tools except in some occasions. It does not depend on interaction, since it occurs only between the instructor and the student, but not always between the learners. Updating of learning materials is not possible because printed books cannot be collected and modified after publication. Traditional learning is scheduled at specific times.Learning opportunities are limited to the ones in the teaching district or region where the student lives. It depends also on the availability of the instructor. Therefore, traditional learning is not available at some times, and needs the classroom.

E-Learning employs new computer technologies, since it depends on multi-electronic means and presentations, discussion methods and web pages. Because it is based on interactivity and multimedia, the learner can easier navigate the electronic presentations and discuss them interactively. Materials are very easy to update, and it costs less to publish them on web than print them. E-Learning is in principle available at any time. Students enjoy the flexibility. It is possible to use the internet from any place, so learning opportunities are available across the world. Additionally, e-Learning depends on self-teaching, since learners learn according to their abilities and interests, and at the speed and times convenient to them.

\section{B. Multimedia Principles}

The term multimedia describes any system that combines two or more media into a single product or presentation such as software program or webpage. Interactive multimedia capabilities are constantly evolving and multimedia have become very popular among educators [1].It provides a more vivid teaching effectiveness and wider development space for e-learning [2].

Some researchers have emphasized the unique contributions that multimedia brings to the learning experience [3][4]. According to Mayer [5], interactive multimedia is 
one of the best technologies to help students learn. However, we should not be overjoyed with the usage of multimedia elements because they may not be incorporated in proper manner[6].Much multimedia research has focused on the specific media employed for instruction. Clark \& Mayer [7] provided a list of several research-based principles for instructional multimedia. Table I presents an overview of multimedia principles and their effect on learning.

\section{PREVIOUS STUDIES}

Many studies have been done that focused on the effects of employing e-Learning environments programs on skills acquisition and achievement to improve teaching.Some studies found that employing e-Learning environments programs improved skills acquisition and achievement, such as Kiboss[8] and Malik [9]. Other studies found that employing e-Learning environments programs did not affect skills acquisition and achievement, such as Fox and Adviser-Lane [10]. The following is a discussion of some of these studies:

The purpose of a study done by Malik [9] was to use a quasi-experimental design to determine whether the use of multimedia-based instructional technology has an effect on urban African American ninth grade students' mastery of algebra concepts.

A pre-test and post-test of algebra concepts was done that compared the results from the treatment group, taught with an interactive whiteboard, and the comparison group taught without any multimedia-based instructional technology occurred. The study sample consisted of 137 African-American ninth grade students in an urban high school in Atlanta, Georgia, USA. Students' post-test scores served as the dependent variable. Independent variables were the degree of integration by students of multimedia-based instructional technology and their gender. Pre-test scores were used as the covariate. Results showed that there were differences with the post-test scores, and that scores were significantly different between the treatment group and control group in students' mastery of algebra concepts, when using multimediabased instructional technology, specifically an interactive whiteboard. There were no significant differences between female and male students in their mastery of algebra concepts when using multimedia-based instructional technology.

In the light of these results, the researcher recommends that educational leaders can utilize the findings of this study to maximize students' achievement in mathematics. The author recommends research into the effectiveness of multimedia-based instructional technology for students with learning disabilities, into single-gender environments compared coeducational schooling, and into instructorstudent perceptions and effectiveness.

The previous study showed that multimedia technologies can open new channels of communication and experiences for pupils in ways that are not possible with traditional methods. The extended resources offered through multimedia, which were not available to the comparison group, might have helped treatment group students achieving higher scores than the traditional groups.

Fox and Adviser-Lane [10] employed a quantitative approach and quasi-experimental design in order to empirically validate specific e-Learning design practices. It in- vestigated how presenting identical instructional content that either applied or failed to apply varied multimedia principles impacted learning, as measured by a comparison of online learners' pre-test and post-test results.

The study sample consisted of 160 participants. They were given a ten-item pre-test on the content and randomly assigned to either one of three experimental groups of 40 students who were presented with ten learning modules designed according to one of the studied principles, or a control group of 40 students who were presented with textual content only. After they finished their learning

TABLE I.

EFFECT OF MULTIMEDIA PRINCIPLES ON LEARNING[7]

\begin{tabular}{|c|c|}
\hline Multimedia Principles & Effect on Learning \\
\hline $\begin{array}{l}\text { Multimedia } \\
\text { using words and pictures }\end{array}$ & $\begin{array}{l}\text { Adding graphics to words can improve } \\
\text { learning. Students learn better from words } \\
\text { and pictures, rather than from words alone. }\end{array}$ \\
\hline $\begin{array}{l}\text { Spatial Contiguity } \\
\text { best placement of words } \\
\text { and pictures }\end{array}$ & $\begin{array}{l}\text { Placing text near graphics improves learn- } \\
\text { ing. Students learn better when correspond- } \\
\text { ing words and pictures are presented close to } \\
\text { each other rather than far from each other. }\end{array}$ \\
\hline $\begin{array}{l}\text { Temporal Contiguity } \\
\text { best sequencing of words } \\
\text { and pictures }\end{array}$ & $\begin{array}{l}\text { Students learn better when corresponding } \\
\text { words and pictures are presented simultane- } \\
\text { ously rather than successively. }\end{array}$ \\
\hline $\begin{array}{l}\text { Coherence } \\
\text { "less is more" }\end{array}$ & $\begin{array}{l}\text { Using gratuitous visuals, text, and sounds } \\
\text { can hurt learning. Students learn better when } \\
\text { irrelevant words, pictures and sounds are } \\
\text { excluded rather than included. Less is more: } \\
\text { eye or ear "candy" can distract and actually } \\
\text { hurt instruction by causing cognitive over- } \\
\text { load. } \\
\text { Visual: Student learning is hurt when inter- } \\
\text { esting but irrelevant words and pictures are } \\
\text { added to a multimedia presentation. } \\
\text { Sound: Student learning is hurt when inter- } \\
\text { esting but irrelevant sounds and music are } \\
\text { added to a multimedia presentation. } \\
\text { Text: Student learning is improved when } \\
\text { unneeded words are eliminated from a } \\
\text { multimedia presentation. }\end{array}$ \\
\hline $\begin{array}{l}\text { Modality } \\
\text { best use of visual and } \\
\text { auditory channels }\end{array}$ & $\begin{array}{l}\text { Explaining graphics with audio improves } \\
\text { learning. Students learn better from anima- } \\
\text { tion and narration than from animation and } \\
\text { only on-screen text. }\end{array}$ \\
\hline $\begin{array}{l}\text { Redundancy } \\
\text { best use of text and audio }\end{array}$ & $\begin{array}{l}\text { Explaining graphics with audio and redun- } \\
\text { dant text can hurt learning. Avoid reading } \\
\text { on-screen text. Students learn better from } \\
\text { animation and narration than from anima- } \\
\text { tion, narration, and on-screen text. }\end{array}$ \\
\hline $\begin{array}{l}\text { Individual Differences } \\
\text { best use of prior } \\
\text { knowledge }\end{array}$ & $\begin{array}{l}\text { Design effects are stronger for low- } \\
\text { knowledge learners than for high-knowledge } \\
\text { learners and for high-spatial learner than for } \\
\text { low-spatial learners. High performing learn- } \\
\text { ers are equipped to use cognitive strategy to } \\
\text { work around cognitive overload, distraction, } \\
\text { or other effects of poor design. Low- } \\
\text { performers are not able to do so. }\end{array}$ \\
\hline $\begin{array}{l}\text { Practice } \\
\text { best interactions for } \\
\text { learning }\end{array}$ & $\begin{array}{l}\text { Frequent, distributed, problem-solving, and } \\
\text { job-context practice improves learning and } \\
\text { knowledge transfer. }\end{array}$ \\
\hline $\begin{array}{l}\text { Learner Control } \\
\text { vs.Program Control } \\
\text { best navigation scheme }\end{array}$ & $\begin{array}{l}\text { Most students in primary or high school } \\
\text { learn more under program control. However, } \\
\text { adult learners require a sense of control to be } \\
\text { able to establish a self-paced learning pro- } \\
\text { cess. Multimedia can accommodate both } \\
\text { groups. }\end{array}$ \\
\hline $\begin{array}{l}\text { Personalization } \\
\text { engaging the learner }\end{array}$ & $\begin{array}{l}\text { Use of conversational tone and pedagogical } \\
\text { agents can increase learning. }\end{array}$ \\
\hline
\end{tabular}


modules, the learners took a post-test to measure the learning during the modules. An ANCOVA statistical test indicated no significant differences in learning between any of the groups, including the control group. It did not make a difference whether learners were presented with text- based content exclusively or with various combinations of multimedia. Learners learned equally well. This study suggest that learners can be highly receptive and adaptive to their learning environment regardless of the instructional media/modality used.

Sears [11] investigated what type of information formatting in an online learning environment best supported comprehension and recollection: static text, static information graphics, animated information graphics, or multimedia information graphics. Further, it aimed to determine if certain data, when strategically emphasized, were recalled more successfully if presented in certain specific formats. In this study, 142 participants viewed one of four online lessons on a community's census statistics. Each lesson was presented in a unique format: as static text, or with static information graphics, or with animated information graphics, or with multimedia information graphics. A quiz was taken by the participants. This was followed by an exit survey.

Results indicated that specific information was recalled more successfully from certain formats. It was also determined that different demographic segments had different format preferences, and that those segments performed better when certain formats were used. The results of this study could be used to guide those who develop and design digital and online materials for education, training, business presentations, and national and international news platforms. The outcomes may be helpful to developers of tablets and smart phones when they seek alternative and concise visual communication solutions. The findings are also of interest to content creators who are searching for Web and digital platforms that aim at a high rate of recollection and who are seeking format preferences for different demographic segments. The researcher concludes that the way of presenting data impact multimedia benefits in learning. Certain data needs a certain format in order to be effectively presented.

Adulseranee[12] compared the differences in the comprehension of a social studies text in local history by Thai seventh graders, using four multimedia formats -written text only (W), written text with graphics (WG), audio with graphics (AG), and written text with audio and graphics (WAG). A post-test 1 - post-test 2 quasi-experimental design was used to collect the data on comprehension. There were 132 seventh grade participants, 85 female and 47 male. A questionnaire collected demographic data and assessed the participants' computer usage and behaviour.

The result showed that the participant in the (W) group scored significantly higher than the other groups on the immediate post-test, and they spent less time completing the learning task. The (WAG) group, however, scored significantly higher than the other groups on the delayed post-test. The findings suggest that pattern recognition and cognitive load may have contributed to higher test score in the $(\mathrm{W})$ group on the immediate post-test. The results add support to dual coding theory and cognitive multimedia learning theory. Results showed that multimedia benefits younger students using a language other than English and content other than science, especially low-previousknowledge learners.

\section{RESEARCH QUESTION AND HYPOTHESES}

In this work the researchers aim to determine the effects of an e-Learning environment on the academic achievement of the $11^{\text {th }}$ grade IT students at the Al-Zobaidea secondary school for girls in Jordan.The following Research Question was studied:

"What is the effect of using e-Courses on the achievement of $11^{\text {th }}$ grade IT students in an Adobe Photoshop Program?"

The following hypotheses were based on the Research Question:

Hypothesis 1: There are differences between the scores of students who are studying Adobe Photoshop program through an e-Course and students who are studying this through the traditional way.

Hypothesis 2: There are differences between the scores of students who are studying Adobe Photoshop program through CFMP and the scores of the students who are studying through CNFMP or the traditional way.

\section{SignificANCE OF THE STUdy}

While the efficacy of the cognitive theory of multimedia learning is generally assumed and this is consistent with dominant educational theory, this efficacy has yet to be definitively demonstrated by empirical research. Many studies have shown the cognitive theory of multimedia learning to be very beneficial in the teaching and learning process but other studies have obtained neutral or negative results.

As more programs and instructors consider the application of the cognitive theory of multimedia learning, the need for more definitive results becomes ever more urgent. More research is needed in order to identify the specific types of programs and instructional circumstances in which applying the cognitive theory of multimedia learning produces superior results.

This study is significant because it adds to the evolving body of research concerning the effect of the cognitive theory of multimedia learning in specific programs on specific culture.

\section{MATERIAL AND METHODS}

The research nature, goals, hypotheses and desired data imposing the use of the experimental method. This method represented in studying the effectiveness of the first independent variable CFMP and the second independent variable CNFMP, and the third independent variable (the traditional method) on the dependent variable (Academic Achievement). The measurement tools will be applied to the three groups before applying the experiment (pre-test) and then the experimental groups will be subject to the independent variables, then after completing the experiment the measurement tools will be applied again to the three groups (post-test), the difference in the results (pre and post tests) for the three groups is the result of the independent variables.

\section{A. Research Sample}

The research sample consisted of 60 Eleventh grade female students in IT branchfrom Al Zubidia secondary school in Jordan studied Adobe Photoshop Program as a part of computer curriculum for the scholastic year 2013. The sample was divided into three groups as follow: 
1. First experimental group learned by using eLearning environment program CFMP, the sample consisted of (20) female students, and taught at the school's computer lab in the computer lessons through the designed and developed website or through CDs.

2. Second experimental group learned by using eLearning environment program CNFMP, the sample consisted of (20) female students, and taught at the school's computer lab in the computer lessons through the designed and developed website or through CDs.

3. The control group learned through the traditional way, the sample consisted of (20) female students, and taught at the classroom or at school's computer lab in the computer lessons using the text-book.

The researcher choose the stratified sample method to choose the study sample because of the variation (heterogeneity) in the study population in terms of the academic achievement, the study population has been divided into categories or classes based on this variance academic achievement.

\section{B. Study Instruments}

The study utilized an achievement test (pre-post test) to measure the student' cognitive abilities in Adobe Photoshop Program, it consists of (50) multiple choice questions.

\section{Research Procedure}

In the light of the research nature, we selected the experimental design known as "pre-post design" by using three equal groups, two of them experimental and the third was the control group.

In this type of designs, the sample was selected and divided into three groups, first and second experimental groups, and the control group. Pre-tests was applied on the three groups before the experiment, and then the first experimental group was subjected to the first independent variable (CFMP), and the second experimental group to the second independent variable (CNFMP), while the control group subjected to the third independent variable (traditional way). After completing the experiment, posttests were applied to the three groups.

\section{E-Courses Description}

The two e-Courses (CFMP and CNFMP) teach the principles of using the Adobe Photoshop program through nine lessons. They explain the concept of digital images and their types. Then the e-courses show the components and tools of Adobe Photoshop and explain how to process digital images by explaining the drawing tools, layers, filters, and text editing. The courses end with ways of adding effects and styles on the images and how to design billboards and magazine pages of and other examples. The lessons included activities and tasks using multimedia tools such as images, audio, movies and Adobe Flash.

\section{RESULTS AND ANALYSIS}

After applying the achievement test to the three groups, we found the following results which summarized in Table II;

A quick glance at Table II implies that all the students in the three groups had benefited from the experiment and improved their academic achievement. To confirm the previous results SPSS was used to analyze the results for the three groups, pre and post results were used in the analyzing process.

TABLE II.

EXPERIMENTAL RESULTS

\begin{tabular}{|l|c|c|c|c|}
\hline & $\begin{array}{c}\text { Achievement } \\
\text { Pre- } \\
\text { testAverage } \\
\text { Out of 50\% }\end{array}$ & $\begin{array}{c}\text { Achievement } \\
\text { Post-test } \\
\text { Average Out } \\
\text { of 50\% }\end{array}$ & $\begin{array}{c}\text { Diff } \\
\text { Out of } \\
\mathbf{5 0 \%}\end{array}$ & $\begin{array}{c}\text { Diff } \\
\text { Out of } \\
\mathbf{1 0 0 \%}\end{array}$ \\
\hline $\begin{array}{l}1^{\text {st }} \text { exp group } \\
\text { CFMP }\end{array}$ & 18.80 & 45.65 & 26.85 & 53.70 \\
\hline $\begin{array}{l}2^{\text {nd }} \text { exp group } \\
\text { CNFMP }\end{array}$ & 17.05 & 39.95 & 22.90 & 45.80 \\
\hline Control group & 18.00 & 33.25 & 15.25 & 30.50 \\
\hline Average & 17.95 & 39.61 & 21.66 & 43.32 \\
\hline
\end{tabular}

Test-retest: (Reliability of the Exam)

The purpose of this test is to check the reliability of the exam by administering the same test twice at two different points in time to the same students.

Phelan and Wren [13] indicated that Test-retest reliability is a measure of the consistency of a psychological test or assessment.

\section{Test-retest:}

A sample of 30 students out of the research sample was taken to test the reliability of the achievement test during two weeks.

It is obvious from Table III that Pearson correlation (r) $=0.800$ is significant at 0.01 level, that there is a significant relationship between pre- and post-test. Therefore, the instruments pass the test-retest test.

TABLE III.

RELIABILITY TEST

\begin{tabular}{|cl|c|c|}
\hline & & Pre & Post \\
\hline Pre & Pearson Correlation & 1 & $0.800^{* *}$ \\
& Sig. (2-tailed) & & 0.000 \\
& N & 30 & 30 \\
\hline Post & Pearson Correlation & $0.800^{* *}$ & 1 \\
& Sig. (2-tailed) & 0.000 & \\
& N & 30 & 30 \\
\hline
\end{tabular}

Pre-test application (Groups Similarity)

T-test:

The study sample included 60 students. We used the previous semester grades records for the computer subject and used the Stratified Sample method to divide the sample into 3 equal groups as mentioned in Material and Methods. To confirm the groups' similarity, the T-test was used to analyze the results for the three groups; pre-test scores were used in the analyzing process. Lowry [14] indicated that the T-test assesses whether the means of two groups are statistically different from each other. This analysis is appropriate whenever you want to compare the means of two groups.

The independent sample test was first used to test the equality between the control group and the second experimental group (CNFMP) as shown in Table IV below.

The $\mathrm{t}$ value $=0.721$ is not significant at the 0.05 level, and therefore, there is no significant differences between 
the two samples in terms of their pre knowledge in Adobe Photoshop Program.

Secondly, the independent sample was used to test the equality between the control group and the first experimental group (CFMP) as shown in Table $\mathrm{V}$ below.

The $t$ value $=-0.637$ is not significant at the 0.05 level, and that means there is no significant differences between the above samples in terms of their pre knowledge in Adobe Photoshop Program.

The independent sample was also used to test the equality between the first experimental group and second experimental group. With reference to Table VI below, it indicates that the calculated $t$ value $=-1.306$ is not significant at 0.05 level, and that means there is no significant differences between the above groups in terms of their pre knowledge in Adobe Photoshop Program.

It was obvious from the results that there are statistically no significant differences at the significance level $(0.05)$ between the averages of the students' degrees of the three groups which means that there is equality between the three groups in the pre-testswhich reflect that the three groups have the samepre knowledge in Adobe Photoshop Program.

TABLE IV.

THE DifFERENCE BETWEEN THE CONTROL GROUP AND THE $2^{\text {ND }}$ EXPERIMENTAL GROUP CNFMP

\begin{tabular}{|cc|c|c|c|c|c|c|}
\hline Group & N & Mean & $\begin{array}{c}\text { Std. } \\
\text { Deviation }\end{array}$ & $\begin{array}{c}\text { Std. Error } \\
\text { Diff }\end{array}$ & $\mathbf{T}$ & Sig \\
\hline \multirow{2}{*}{ Results } & Control & 20 & 18.0000 & 3.89331 & 1.31684 & 0.7210 & 0.475 \\
& CNFMP & 20 & 17.0500 & 4.41856 & 1.31684 & & \\
\hline
\end{tabular}

TABLE V.

DIFFERENCE BETWEEN THE CONTROL GROUP AND THE $1^{\text {st }}$ EXPERIMENTAL GROUP CFMP

\begin{tabular}{|c|c|c|c|c|c|c|}
\hline Group & N & Mean & $\begin{array}{c}\text { Std. } \\
\text { Deviation }\end{array}$ & $\begin{array}{c}\text { Std. Error } \\
\text { Diff }\end{array}$ & T & Sig \\
\hline \multirow{2}{*}{ Results Control } & 20 & 18.0000 & 3.89331 & 1.25572 & - & \\
CFMP & 20 & 18.8000 & 4.04709 & 1.25572 & 0.637 & 0.528 \\
\hline
\end{tabular}

TABLE VI.

DIFFERENCE BETWEEN THE $1^{\text {ST }}$ EXPERIMENTAL GROUP CFMP AND $2^{\text {ND }}$ EXPERIMENTAL GROUP CNFMP

\begin{tabular}{|cc|c|c|c|c|c|c|}
\hline Group & N & Mean & $\begin{array}{c}\text { Std. } \\
\text { Deviation }\end{array}$ & $\begin{array}{c}\text { Std. Error } \\
\text { Diff }\end{array}$ & T & Sig \\
\hline \multirow{2}{*}{ Results } & CNFMP & 20 & 17.0500 & 4.41856 & 1.33983 & - & \\
& CFMP & 20 & 18.8000 & 4.04709 & 1.33983 & 1.306 & 0.199 \\
\hline
\end{tabular}

\section{Post-test application:}

ANCOVA Test:

ANCOVA, short for Analysis of Covariance, is a statistical test to determine the covariance between variables. It is a measure of how much two variables change together and how strong the relationship is between them. When ANCOVA is used with three or more groups, then we have at least three ways to test.

We could take them two at a time, instead of using a mean difference, or we can use the variance of the group means of the grand mean over all groups.

After analyzing the achievement test, we found the following results:
TABLE VII.

ACHIEVEMENT TEST EXPERIMENTAL RESULTS FOR THE $1^{\text {ST }}$ EXPERIMENTAL GROUP CFMP AND CONTROL GROUP

\begin{tabular}{|l|c|c|c|c|}
\hline & $\begin{array}{c}\text { Achievement } \\
\text { Pre-testAverage } \\
\text { Out of 50\% }\end{array}$ & $\begin{array}{c}\text { Achievement } \\
\text { Post-test Average } \\
\text { Out of 50\% }\end{array}$ & $\begin{array}{c}\text { Diff } \\
\text { Out of } \\
\mathbf{5 0 \%}\end{array}$ & $\begin{array}{c}\text { Diff } \\
\text { Out of } \\
\mathbf{1 0 0 \%}\end{array}$ \\
\hline $\begin{array}{l}1^{\text {st }} \text { exp group } \\
\text { CFMP }\end{array}$ & 18.80 & 45.65 & 26.85 & 53.70 \\
\hline Control group & 18.00 & 33.25 & 15.25 & 30.50 \\
\hline
\end{tabular}

Table VII above shows that there are differences between the averages of scores between the $1^{\text {st }}$ experimental group and control group in the pre and post tests in favor of the post tests which means that the student' achievement in the two groups increased after applying the experiment, and the same table also shows that there is difference between the averages of the post tests between the two groups in favor of the $1^{\text {st }}$ experimental group CFMP. To confirm these results we use ANCOVA test as follows;

TABLE VIII.

DIFFERENCES BETWEEN THE $1^{\text {ST }}$ EXPERIMENTAL GROUPCFMP AND THE CONTROL GROUP IN THE POST ACHIEVEMENT TEST USING ANCOVA

\begin{tabular}{|c|c|c|c|c|c|}
\hline Source & $\begin{array}{c}\text { Type III sum } \\
\text { of squares }\end{array}$ & Df & $\begin{array}{l}\text { Mean } \\
\text { square }\end{array}$ & $\mathbf{F}$ & Sig. \\
\hline $\begin{array}{l}\text { Pre versus post } \\
\text { for CFMP }\end{array}$ & 574.698 & 1 & 574.698 & 15.821 & 0.000 \\
\hline $\begin{array}{l}\text { Post CFMP } \\
\text { versus Control } \\
\text { Group }\end{array}$ & 489.646 & 1 & 489.646 & 13.479 & 0.001 \\
\hline Error & 1344.052 & 37 & 36.326 & & \\
\hline
\end{tabular}

Dependent Variable: Post

It is seenfrom Table VIII that $F=15.821$ and $d f=1$ which means that there is statistically significant difference at the significance level (0.05) between the average of the students' scores $1^{\text {st }}$ experimental group and the control group in the pre and post application of the achievement test in favor of the post application, which means that the student' achievement in the CFMP group increased after applying the experiment.

It was found that $F=13.479$ as shown in Table VIII above, which means that there are statistically significant differences at the significance level $(0.05)$ between the average of the scores of the first experimental group and the average of the scores of the control group of the achievement test post-application in favor of the first experimental group.

TABLE IX.

ACHIEVEMENT TEST EXPERIMENTAL RESULTS FOR THE $2^{\text {ND }}$ EXPERIMENTAL GROUP CNFMP AND CONTROL GROUP

\begin{tabular}{|l|c|c|c|c|}
\hline & $\begin{array}{c}\text { Achievement } \\
\text { Pre-testAverage } \\
\text { Out of 50\% }\end{array}$ & $\begin{array}{c}\text { Achievement } \\
\text { Post-test Aver- } \\
\text { age Out of 50\% }\end{array}$ & $\begin{array}{c}\text { Diff } \\
\text { Out of } \\
\mathbf{5 0 \%}\end{array}$ & $\begin{array}{c}\text { Diff } \\
\text { Out of } \\
\mathbf{1 0 0 \%}\end{array}$ \\
\hline $\begin{array}{l}\text { Pre vs. post } \\
\text { for }\end{array}$ & 17.05 & 39.95 & 22.90 & 45.8 \\
\hline $\begin{array}{l}\text { CNFMP } \\
\text { group }\end{array}$ & 18.00 & 33.25 & 15.25 & 30.50 \\
\hline
\end{tabular}

Table IX above shows that there are differences between the averages of scores between the $2^{\text {nd }}$ experimental group and control group in the pre and post tests in favor of the post tests which means that the student' achievement in the two groups increased after applying the exper- 
iment, and the same table also shows that there is difference between the averages of the post tests between the two groups in favor of the $2^{\text {nd }}$ experimental group CNFMP. To confirm these results we use ANCOVA test as follows:

TABLE X.

DIFFERENCES BETWEEN THE $2^{\mathrm{ND}}$ EXPERIMENTAL GROUP CNFMP AND THE CONTROL GROUP IN THE POST ACHIEVEMENT TEST USING ANCOVA

\begin{tabular}{|l|c|c|c|c|c|}
\hline Source & $\begin{array}{c}\text { Type III sum of } \\
\text { squares }\end{array}$ & Df & Mean square & F & Sig. \\
\hline Pre & 515.042 & 1 & 515.042 & 10.470 & .003 \\
Group & 212.553 & 1 & 212.553 & 4.321 & .045 \\
Error & 1820.108 & 37 & 49.192 & & \\
\hline
\end{tabular}

Dependent Variable: Post

It is seen from Table $\mathrm{Xthat} F=10.470$ and $d f=1$ which means that there is statistically significant difference at the significance level (0.05) between the average of the students' scores of the two groups $\left(2^{\text {nd }}\right.$ experimental group and control group) in the pre and post application of the achievement test in favor of the post application, which means that the student' achievement in the two groups increased after applying the experiment.

It was found that $F=4.321$ as shown in Table $\mathrm{X}$, which means that there are statistically significant differences at the significance level $(0.05)$ between the average of the degrees of the second experimental group that used (CNFMP) and the average of the degrees of the control group of the post-application of the achievement test in favor of the second experimental group.

TABLE XI.

ACHIEVEMENT TEST EXPERIMENTAL RESULTS FOR THE $1^{\text {ST }}$ EXPERIMENTAL GROUP CFMP AND $2^{\mathrm{ND}}$ EXPERIMENTAL GROUP CNFMP

\begin{tabular}{|l|c|c|c|c|}
\hline & $\begin{array}{c}\text { Achievement } \\
\text { Pre-testAverage } \\
\text { Out of 50\% }\end{array}$ & $\begin{array}{c}\text { Achievement } \\
\text { Post-test Aver- } \\
\text { age Out of 50\% }\end{array}$ & $\begin{array}{c}\text { Diff } \\
\text { Out of } \\
\mathbf{5 0} \%\end{array}$ & $\begin{array}{c}\text { Diff } \\
\text { Out of } \\
\mathbf{1 0 0} \%\end{array}$ \\
\hline $\begin{array}{l}1^{\text {st }} \text { exp group } \\
\text { CFMP }\end{array}$ & 18.80 & 45.65 & 26.85 & 53.70 \\
\hline $\begin{array}{l}2^{\text {nd }} \text { exp group } \\
\text { CNFMP }\end{array}$ & 17.05 & 39.95 & 22.90 & 45.80 \\
\hline
\end{tabular}

Table XI above shows that there are differences between the averages of scores between the $1^{\text {st }}$ experimental group and $2^{\text {nd }}$ experimental group in the pre and post tests in favor of the post tests which means that the student' achievement in the two groups increased after applying the experiment, and the same Table also shows that there is difference between the averages of the post tests between the two groups in favor of the $1^{\text {st }}$ experimental group CFMP. To confirm these results we use ANCOVA test as follows:

TABLE XII.

ACHIEVEMENT TEST EXPERIMENTAL RESULTS FOR THE $1^{\text {ST }}$ EXPERIMENTAL GROUP CFMP AND $2^{\mathrm{ND}}$ EXPERIMENTAL GROUP CNFMP USING ANCOVA

\begin{tabular}{|l|c|c|c|c|c|}
\hline Source & $\begin{array}{c}\text { Type III sum } \\
\text { of squares }\end{array}$ & Df & Mean square & F & Sig. \\
\hline Pre & 200.487 & 1 & 200.487 & 6.197 & .017 \\
Group & 178.139 & 1 & 178.139 & 5.506 & .024 \\
Error & 1197.013 & 37 & 32.352 & & \\
\hline
\end{tabular}

Dependent Variable: Post
It is obvious from Table XII above that $F=6.197$ which means that there is statistically significant difference at the significance level $(0.05)$ between the average of the students' scores of the two groups $\left(1^{\text {st }}\right.$ experimental group and $2^{\text {nd }}$ experimental group) in the pre and post application of the achievement test in favor of the post application, which means that the student' achievement in the two groups increased after applying the experiment.

It was found that $F=5.506$ as shown in Table XII above, which means that there are statistically significant differences at the significance level (0.05) between the average of the degrees of the first experimental group that used CFMP and the average of the degrees of the second experimental group used CNFMP of the post-application of the achievement test in favor of the first experimental group.

The previous results for the achievement test show that the average grade for the students studying through the two e-Courses are higher than the average of the degrees for the students studying by traditional way and this prove hypothesis no 1 . Also, the average of degrees for the students studying through CFMP are higher than the average of the degrees for the students studying by CNFMP or traditional way and this prove hypothesis no 2 .

\section{DISCUSSION OF THE RESULTS}

The analysis of achievementtest results show that the students studying through CFMP had improved their academic achievement by $53.70 \%$, while the students studying through CNFMP improved by $45.80 \%$. The students studying through the traditional way had improved their achievement only by $30.50 \%$, which means that there are significant and large differences between the average score of the students who are studying Adobe Photoshop Program through multimedia e-Courses and the average scores of the students who are studying through the traditional way in favor of the e-Courses and this proved thehypothesis no. 1 .

The analysis also shows that there are differences between the average scores of students who are studying Adobe Photoshop skills through the CFMP and the average of the students' scores who are studying through CNFMP or traditional way in favor of CFMP. This proved hypothesis no. 2 .

We can answer the Research Question now according to the previous discussion.Use of e-Courses increased the achievement of the 11th grade IT students in this multimedia Adobe Photoshop Program and we can attribute this result to the following reasons:

1. Employing the multimedia properly in the educational process through applying the multimedia principles has improved the students' ability to comprehend, and helped them in achieving higher scores.

2. The multimedia online e-Course makes reviewing any unclear information or searching for any explanations or additional information easier when multimedia principles are followed. Additionally, the information that the student obtains through searching will be easier to remember.

3. e-Quizzes tool which the student resolve after finishing each lesson helped in self-evaluation, and helped in knowing and reviewing the mistakes.

The current study is consistent with Kiboss[8], Malik [9], and Kingsley \& Boone [15] studies. Those empha- 
sized that employing e-Learning environments programs improved skills acquisition and academic achievement. This study also confirms that multimedia technologies can open new channels of communication and experiences for pupils. The extended resources offered through multimedia might have helped the treatment group students achieving higher scores than the traditional groups.

\section{CONCLUSION}

This research presented herein strove to test the cognitive theory of multimedia learning in an e-learning environment in an Adobe Photoshop course for female students of a Jordan secondary school. The study used an experimental design to determine whether the use of two proposed e-Courses (CFMP, CNFMP) had an effect on students' academic achievements in the target sample more than when using the traditional learning way.

SPSS was used to analyze the scores of the experimental groups and control group. Differences between post-test scores affirms that CFMP has more effect on student academic achievement than the traditional way or the CNFMP. This indicates that employing the cogitative theory of multimedia learning properly in the educational process has improved the students' ability to comprehend, and helped them in achieving higher levels in learning.Educators should evaluate the effective educational strategies and technologies to increase student's achievement. It was noted that multimedia-based educational technology was beneficial to students' learning when combinations of visual and verbal forms to present the information were used.

In an increasingly diverse multicultural educational environment, teaching and learning strategies which accommodate different learning styles, instructional preferences, and educational aims are increasingly important. Employing the cognitive theory of multimedia learning has the potential to make a great difference in this regard. For example, students for whom English is a second language may have difficulty understanding lecture material. Carefully designed computer-facilitated multimedia instruction allows students to take as much time as they need with verbal material and provides visual aids to clarify words which may be unclear out of context. Finally, when investing in educational resources, educational leaders should consider the ability of multimedia-based educational technology to provide multiple learning modalities to meet the needs of all students and keep pace with the rapid development in e-Learning environments.

\section{REFERENCES}

[1] J. Lockard, and P. Abrams, "Computers for twenty-first century educators," Pearson Education, 2003.

[2] S. Nie, and Y. Liu, "The Design and Application of Computer Aided Instruction Courseware," In Information Management, Innovation Management and Industrial Engineering (ICIII), 2011 International Conference, IEEE, Vol. 1, November 2011, pp.453455). http://dx.doi.org/10.1109/iciii.2011.115

[3] N.Brouwer, G. Muller, andH.Rietdijk, "Educational designing with MicroWorlds,"Journal of Technology and Teacher Education, 15(4), pp. 439-462, 2007.

[4] A. D.Thompson, "Scientifically based research: Establishing a research agenda for the technology in teacher education communi-
ty,"Journal of Research on Technology in Education, 37(4), pp. 331-337, 2005. http://dx.doi.org/10.1080/15391523.2005.107824 40

[5] R. E. Mayer, "The promise of multimedia learning: using the same instructional design methods across different media,"Learning and instruction,13(2), pp. 125-139, 2003. http://dx.doi.org/10.1016/ S0959-4752(02)00016-6

[6] Y. W. Li, N. Mai, and N. Tse-Kian, "Using Mayer's Design Principles in Online Learning Modules: Implementation in a Student Centred Learning Environment," In Informatics and Creative Multimedia(ICICM), 2013 International Conference, IEEE, September 2013, pp.304-309.

[7] R. C. Clark, and R. E.Mayer, "E-learning and the science of instruction: Proven guidelines for consumers and designers of multimedia learning," John Wiley \& Sons, 2011. http://dx.doi.org/10.1002/9781118255971

[8] J. K. Kiboss, "Influence of E-Learning Environment Program on Pupils' Instructional Approaches in Physics Measurement Lessons in Kenyan Secondary Schools,"Creative Education, 2(03), pp. 244, 2011. http://dx.doi.org/10.4236/ce.2011.23033

[9] I. Z.Malik, "Effects of Multimedia-Based Instructional Technology on African American Ninth Grade Students' Mastery of Algebra Concepts," ProQuest LLC, 2011.

[10] K. D. Fox, and C.Adviser-Lane, "Investigating the impact of multimedia design principles on learning in an online context,"ProQuest LLC, 2010.

[11] R. B.Sears, "Evaluating the effectiveness of multimedia information graphics in the learning environment," TEXAS A\&M UNIVERSITY-COMMERCE, 2012.

[12] R.Adulseranee, "The effects of using different types of multimedia presentations on The seventh grade learners' understanding of a social studies text,"E-Learn 2007 World Conference on ELearning in Corporate, Government, Healthcare, \& Higher Education, Quebec city, Quebec, Canada: AACE, 2007.

[13] C. Phelan, J.Wren,"Exploring Reliabilityin Academic Assessment," Retrieved from University of Northern lowa: http://www.uni.edu/chfasoa/reliabilityandvalidity.htm, 2013, May 13.

[14] R.Lowry, "Concepts and applications of inferential statistics,'Retrieved from Vassar College: http://vassarstats.net/ textbook/ 2014.

[15] K. V. Kingsley, and R.Boone, "Effects of multimedia software on achievement of middle school students in an American history class,"Journal of Research on Technology in Education, 41(2), pp. 203-221, 2008. http://dx.doi.org/10.1080/15391523.2008.107825 29

\section{AUTHORS}

Wesam Karajeh completed his master degree in Information Systems at the University of Jordan and currently is an IT teacher with the Ministry of Education. Department of Computer Information Systems, the University of Jordan, Amman, Jordan 11942 (e-mail: wesam_karajeh@yahoo.com).

Thair Hamtini., is an associate professor with the Computer Information Systems Department at the University of Jordan, Amman, Jordan 11942. (e-mail: thamtini@ju.edu.jo).

Meysun Hamdi is an e-Learning developer and completed her master degree in Information Systems at the University of Jordan, Amman, Jordan 11942.(e-mail: maisoonhamdi@gmail.com).

Submitted 18 December 2016. Published as resubmitted by the authors 16 February 2016. 